\title{
The Role of Effective Accounting System on Import-Export Trade in Ethiopia: The Case of Anbessa Shoe Share Company
}

\author{
Fekadu Agmas Wassie \\ Department of Accounting and Finance, Debark University, Debark, Ethiopia \\ E-mail: fekaduagmas2005@gmail.com
}

Received: May 15, 2019 Accepted: July 20, $2019 \quad$ Published: July 24, 2019

doi:10.5296/ieb.v5i2.15142 URL: https://doi.org/10.5296/ieb.v5i2.15142

\begin{abstract}
The main purpose of this study is to examine the role of effective accounting system on import-export trade in Anbessa Shoe Share Company. This study is focused on Ethiopian import-export companies specifically, Anbessa Shoe Share Company and there are 208 target populations considered in the study who are accountants and some higher management personnel's employing in Company. Randomly selected 51 accountants and some higher management personnel of the company are the source of the necessary data to the researcher through the administered questionnaires and interviews. Besides, the objective of this study is to assess the role of proper and effective accounting system employment on import-export trade in Anbessa Shoe Share Company. According to the study findings, an effective accounting system have an important role on import-export trades of the company. In addition, based on the non-parametric test made using Chi-Square distribution the accountant's competency measured in terms of their profession, educational level and work experience was statistically not significance. The company should understand that the contributions of effective accounting system on its import-export trade is very vital for those activities performed in its trade and for the overall performances.
\end{abstract}

Keywords: Effective accounting system, Import-export trade, Ethiopian import-export companies, Anbessa Shoe Share Company

\section{Background of the Study}

Almost all countries are usually involved in import-export trade through international foreign markets. Mostly many countries are involved in such type of trade in order to get many advantages. Such advantage may express in the form of absolute and comparative advantage. As stated by Smith (1937), Absolute advantage means when one nation is more effective than 
another in the production of one commodity but less effective than the other nations in manufacturing second artifact, then each nations will gain by every specializing within the production of the artifact of its absolute advantage and exchanging a part of its output with the other nation for the artifact of its absolute advantage. As Ricardo (1817) states, comparative advantage will be expressed as even if nations are less effective than other nation in the production of both commodities, there is still a base for mutually beneficial trade.

Import-export trade in the international market is the major concerns of different nations as it has a significant role on growth and expansion of their economy (Meade, 1951). Even though international trade cannot generally be expected to be an "Engine of Growth", today, there are still many ways during which it will contribute to the economic growth of today's developing nation. Haberler (1964), among others, has pointed out the following important beneficial effect that international trade can have an economic development; trade can lead to the full utilization of otherwise underemployed domestic resources. By expanding the size of the market, trade also makes possible division of labor and economic of scale. It is also the vehicle for the transmission of new ideas, new technology, and new managerial and other skills. Furthermore, trade also stimulates and facilitates the international flow of capital from developed to developing nations. Not only this but also in several large developing nations the importation of new manufactured products simulated domestic demand until effective domestic production of thus goods become feasible. Finally, international trade is excellent antimonopoly weapon because it stimulates greater efficiency by domestic producers to meet foreign computation.

Usually, more emphasis is given for international trade because of it has a positive relationship with long run economic growth and development. This positive relationship may improve by the proper and effective implementation of accounting principles and procedures on the sector. Accounting plays a crucial role in our economic and social organization. Sound decision made by individuals, businesses, governments, and other entities are essential for the effective distribution and use of the nation's scarce resource. To make such decisions, thus groups must have reliable information provided by the accounting system. The objective of accounting, therefore, is to record, summarize, report, and interpret economic data for use by many groups within our economic and social system (Warren, 2006). For Anbessa Shoe Share Company and others groups involved in the international trade accounting system has its own role for their performances and operational activities.

Thus, the participant groups need to apply the accounting system principles and procedures which is used to asses and evaluate events and transactions which take place between them for making future sound decisions. Even if the system has a role on the sector, the ability and quality of accountants may affect the information produced through accounting system. Like Anbessa Shoe Share Company, many companies are applying the accounting system principles and procedures in their day to day activities, but do not dare to say that they are being apply it effectively.

Indeed, in the long run existence of an organization the effectiveness of accounting system has significant role for various sound decisions. Thus, ineffective employment of accounting system principles and procedures in the sector will create different sorts of problems. On this 
issue only few studies have been made and some studies are focuses on only taxing matters of the sector, and others are mainly focuses on marketing efficiency of the sector (Berhe, 2009; Abdulkadir, 2002), however, the problems raised with related to the effective employment of accounting system is remains an open question. This study was attempted to contribute to the knowledge base by exploring the role of accounting system on import-export trade in Anbessa Shoe Share Company.

In most manufacturing companies which are involved in foreign international market like Anbessa Shoe Share Company one of the most basic systems used to provide reasonably insurable, realizable, and creditable information for decision makers is an overall accounting system principles and procedures (Eliffson, 2006). According to Salvatore (2011), as import-export trade is a vital source of revenue for developing countries like Ethiopia, the proper employment and efficiency of accounting system has an important role on the operations of the company in particular and the country's economy in general. This is due to accounting is often referred to as the" Language of Business" (Warren, 2006). This language will viewed as a system that gives essential data concerning the economic activities of an entity to varied people or teams for its use in crafting informed judgment and decisions.

Thus, if properly and effectively employs, accounting system can give argent importance to sound decisions made by individuals, businesses, governments, and other entities for the effective distribution and use of the nation's scarce resources. As the strength of accounting system pulls the company up, so its poor efficiency and performance will push the company journey down. This is because, the poor efficiency of the system leads different group of decision makers to make wrong decisions (Warren, 2006).

According to Eliffson (2006), the information provided by the ineffective system is not reasonable, realizable, and creditable for sound judgments and decisions made by decision makers and this will let the company go to the wrong way and expose the company to its failure and finally this will affect the country's economic growth and development as a whole. Therefore, this study was undertaking to assess the role of proper and effective accounting system employment on import-export trade in Anbessa Shoe Share Company. To reach this research objective the following research questions and a hypothesis was made:

1). What role dose accounting system have on import-export trade in Anbessa Shoe Share Company?

2). How does the accounting system principles and procedures are being effectively applied?

$3)$. What roles dose the accounting systems play to contribute for the overall economy?

In addition, in order to get insight in to the main objective of the research, the researcher was also analyzed the following hypothesis:

Null Hypothesis $\left(H_{0}\right)$ : There is no statistically significant relationships exist between the effectiveness of accounting system and accountant's competency

\section{Development of Accounting System}

Accounting has evolved, as have medicine, law, and other most fields of human activity, in response to the social and economic needs of society. According to Warren (2006), as business society have become more complex over the years, accounting has developed new concepts and techniques to meet the ever-increasing needs for financial information. Without 
such information many complex economic developments and social programs might never have been undertaken.

Peoples of all old civilizations have maintained numerous forms of records of business activities. The oldest acknowledged are "clay tablet" records of payment of wages in Babylonia around 3600 B.C. There are numerous evidences of record keeping and systems of accounting in ancient Egypt and in the Greek city-states. The earliest English records were compiled at the direction of William the Conqueror in the eleventh century to ascertain the financial resource of the kingdom (Warren, 2006). For the most part, early accounting dealt only with limited aspects of the financial operation of private or governmental enterprises. There was no systematic accounting for all transactions of a particular event, only for specific types or portions of transactions. Complete transactions for an enterprise developed somewhat latter in response to the needs of the commercial republics of Italy (Warren, 2006).

When the resources of a number of people were pooled to finance a single venture, such as a voyage of merchant ship, the double entry system provided records and reports of income of the venture and the equity of the various participants. As single ventures were replaced by more permanent business organizations, the double-entry system was easily adopted to meet their needs. In spite of the tremendous development of business operations since 1494, and the ever increase complexities of business and governmental organizations, the basic elements of the double-entry system have continued virtually unchanged (Warren, 2006).

Accounting is capable of supplying financial information that is essential for the effective operation and for the evaluation of performance of any economic unit in society changes in environment in which such organizations operate will inevitably be accompanied by alternations in accounting concepts and techniques. Accounting plays a crucial role in our economic and social organization. Sound decisions made by individuals, businesses, governments, and other entities are essential for the effective distribution and use of the nation's scarce resources. To make such judgments, these teams should have reliable figures provided by the system. The objective of accounting, therefore, to record, summarize, report, and interpret economic data for use by many groups within our economic and social system (Weygandt, 1993).

According to Warren (2006), accounting is often called the "Language of Business". This language will viewed as a system that gives essential data concerning the economic activities of an entity to varied people or teams for his or her use in creating informed judgments and decisions. As such, accounting figures consists primarily of economic activities regarding business transactions, expressed in terms of cash. The mere records of transactions are of little use in making informed judgments and decisions. The recorded data must be sorted and summarized and the presented in significant reports. The usefulness reports are often improved by various kinds of percentage and trend analysis.

Accounting provides the technique for gathering economic data ant the language for communicating these data to different individuals and institutions. Investors in a business organization require report concerning its economic standing and its future prospects. Bankers and suppliers appraise the financial soundness of a business organization and assess the risk involved before making loans or granting credit. Government agencies are involved with the economic activities of business organizations for the functions of taxation and 
regulation. Employees and their representatives are also vitally interested in the stability and the profitability of the organization that hires them (Larson, 1990).

In accounting, as in the physical and biological sciences, experimentation and change are never ending. Capable scholars devote their lives and their intellectual energies to the development of accounting principles. Experienced professional accountants contribute their best thinking to the solution of problems continually confronting their client or employers. Professional accounting association periodically issue pronouncements on accounting principles. Authoritative accounting announcements are issued by such bodies as the Financial Accounting Standard Board (FASB). It is form research, accepted accounting practice, and pronouncements of professional and authoritative bodies that generally accepted accounting principles evolve to form the understanding base for accounting practice (Warren, 2006). According to Weygandt (1993), every profession develops a body of theory consists of principles, assumptions, concepts, and standards. Accounting is no exception. Just a doctor follows certain standards in accounting a patient's illness, an accountant follows certain standards in reporting financial information. The accounting profession has tried to develop a group of standards that's typically accepted and universally practiced. Its efforts have resulted in a common set of standards called generally accepted accounting principle (GAAP). These standards indicate how to report economic events (Weygandt, 1993).

Accounting system is the design and implementation of procedures for the accumulation and reporting of financial data. According to Warren (2006), the system accountant must devise appropriate "check and balances" to safeguard business properties and provide for information flow that will be effective and helpful to management. Familiarity with the uses and relative merit of various data processing methods, including computer hardware and software, is also essential (Weygandt, 1993).

\section{Accounting System and Import-Export Trade}

The available research results for accounting system in Ethiopia are outdated. Current knowledge on accounting system's structure, performance and efficiency is poor and inadequate for various decision making and institutions to overcome perceived problems in the import export trading systems (Abdulkadir, 2002). Exports are the main source of revenue for nations through trading domestic products in the international market.

As stated by Derrese (2001), like most developing countries, Ethiopia's export trade, is highly determined and dominated by agricultural commodities such as coffee and oil seeds. On one side, Livestock is also another major export sector for Ethiopia. The share of live animal exports in total livestock and livestock products export earnings have declined in recent years. Other main item of export is leather products. The countries leather industry has witnessed tremendous growth since 2005, which is mostly due to large scale private investment. Skins and hides exports redoubled throughout this era whereas meat exports remained comparatively constant (Zewdu, 1995). There has been a marked growth in the establishment of new private tanneries in Ethiopia since 1992, though many of them don't operate at full capacity due to shortages in raw skins and hides supplies.

Most of the skins and hides exported are semi-processed (as pickled, wet blue or crust). Finished leather goods and articles like shoe are produced mainly for the domestic market 
and to some extent for the export markets. Hides and skins generate the second foreign exchange earnings after coffee (Yakob, 2002).

As the industry have a greatest role on the economy of the country, proper control and evaluation mechanisms of those sectors operation should be needed. Thus, accounting system, through different analytical mechanisms, can masseur the performance and position of different traders in the industry of leather and shoe products. In general, in different cross-border trade outlets, prices do not move in the same direction, indicating some sort of market failure. The advantage of applying the accounting system permits the development of an integrated approach to the analysis of problems and constraints throughout an industry, thus leading to the identification of solutions to problems within specific components that will positively affect other components, and the value chain as a whole (UNIDO, 2004). The leather value chain begins with animal husbandry, the source of its raw materials. Then continue to marketing of hides and skins, the basic raw material, and the marketing of intermediate and of final products such as shoes. The leather value chain, with all the inputs, policies and support system that it requires, is clearly a high complex system, where problems and constraints and the search for their solutions are interrelated (UNIDO, 2004). Thus, domestically produced shoe products have been taken as one of the major important marketable commodities for the purpose of this study.

Generally, in the long run existence of an organization the effectiveness of accounting system has significant role for various sound decisions. Thus, ineffective employment of accounting system principles and procedures in the sector will create different sorts of problems and will affects the creation of value chain, as it is one determinant factor in the value chain. Some studies are focuses on only taxing matters of the sector, and others are mainly focusing on marketing efficiency of the sector (Berhe, 2009; Abdulkadir, 2002), however, the problems raised with related to the effective employment of accounting system is remains an open question. This study was attempted to contribute to the knowledge base by exploring the role of accounting system on import-export trade a case in Anbessa Shoe Share Company. This paper is aimed at assessing the proper and effective employment of accounting system in the company. To achieve the specified important objectives and answer both research questions and hypothesis of the study, the researcher is going to use appropriate methodological procedures.

\section{Methodology of the Study}

This research paper was aimed at assessing the role of proper and effective employment of accounting system on import-export market in Anbessa Shoe Share Company. To achieve these important objectives and answer both research questions and hypothesis, it is good to use mixed method than other methods. This is because quantitative methods are essential for analyzing relationship between variables systematically and help to test hypothesis; in addition to these quantitative methods also helpful for statistical techniques aided by computational algorithms and software package for analysis. On the other hand, qualitative methods will be helpful for studying documents and different transcripts, case histories, and carry out interviews. These reasons make mixed method better than others to achieve the objective of the paper.

The study was mainly used one source of data which is primary source of data. This research 
work was made usage of primary data mainly through the employment of questionnaires and interviews which were administered to employees of the company. Specifically, the primary data source was collected from accountants and some higher management personnel's employing in the company. This is because it suits the type of inquiry that was being conducted by the researcher, and the availability of funds and time had also been adequate in order to undertake it.

The population for the study was accountants and some higher management personnel's employing in Anbessa shoe Share Company. Those groups of the company were selected because of the fact that, since the accountants and higher-level managements are involved in import-export trade of the company both directly and indirectly, it makes it easy to measure the role of accounting system and its effectiveness on import-export trade. Now a day's Anbessa Shoe Share Company has a number of its own retail locations in Addis Ababa and in the Regional States. Due to this the number of accountants on the activities of the company increases proportionally. In this study the researcher was used both probability sampling and non-probability sampling technique to determine the sample size. The researcher was used probability sampling to determine the sample units participate in the survey and total population size of those groups is amounted to be 208. Of this identified population, the sample was selected by using simple random probability sampling and out of the population 52 accountants and higher management personnel were selected and required to fill the questionnaire. The following formula were used to determine sample size for the finite population of the study (Kothari, 2004) by taking the average present ineffectiveness of the accounting practice in Ethiopia on the basis of prior study was $25.5 \%$, acceptable magnitude or error (E) of 5\%, and confidence level (Z) of 95\%.

$$
\begin{gathered}
n=\frac{Z^{2} \times p \times q \times N}{E^{2}(N-1)+Z^{2} \times p \times q} \\
=\frac{(0.95)^{2} \times 0.745 \times 0.255 \times 208}{(0.05)^{2} \times(208-1)+(0.95)^{2} \times 0.745 \times 0.255}=52
\end{gathered}
$$

Where;

$n=$ Sample size

$p=$ Effective population proportion

$q=1-p$

$Z=$ Confidence level

$E=$ Acceptable magnitude of error

The last specific objectives of the study were required to look the role of accounting system and the association of quality and ability of accountants with it, which required to see the dependence of one factor over the other. To achieve this, the researcher was used the test of dependence called chi-square test and it was analyzed with the interview result and other documents in a critical and wise manner. Moreover, to overview the role of accounting system on import-export trade applied in Anbessa Shoe Share Company as well as to determine 
whether the accounting system principles and procedures are being effectively applied, the findings of all data collected had been analyzed using descriptive statistics such as frequency table of percentage and all data's were described through graphs and pie charts.

\section{Results and Discussion}

As it was mentioned, the overall objective of this research is to assess the proper and effective accounting system employment in Anbessa Shoe Share Company to know whether the company is receiving full benefit from the accounting system principles and procedures employment in its import-export trade activities. Of the different methods, mixed qualitative-quantitative methods were selected as a research method. Under quantitative method, survey method was believed to be the best method to achieve the research objective and answer both the research questions and the hypothesis. Out of the 208 accountants and higher managements, the researcher selects 52 sample sizes, in which the self-administrative questionnaires were distributed for analysis. Out of the distributed questionnaire 46 were collected with a great effort of the researcher and it testifies that the response rate was $88.46 \%$. Thus, the response rate is well-enough to go through the study and the analysis of this paper was made by using frequency table, pie chart, and qui-square test.
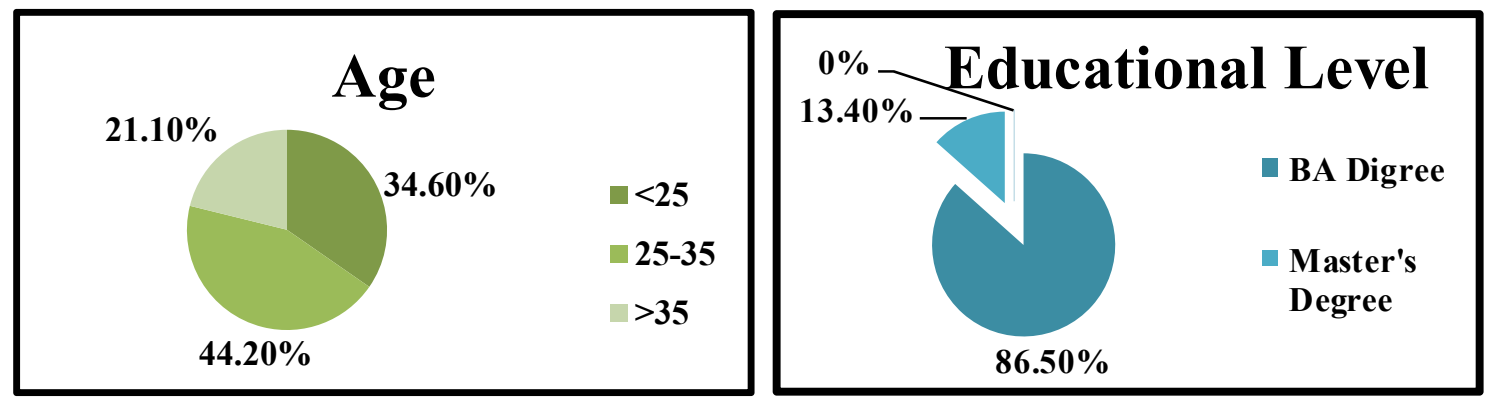

Pie chart 1. Description of respondents with respect to their age and gender

As indicated in the pie chart 1 above, the age composition of the respondents with a percentage of $34.6 \%$ were found less than $25,44.2 \%$ were between $25-35$, and $21.1 \%$ were above 35 age. From this the researcher found out that most of the respondents were between25-35. Furthermore, out of the total of respondents $57.7 \%$ were males and about $42.3 \%$ were females. This implies that workers in the company are more of males and accounting related activities are largely performed by them. 

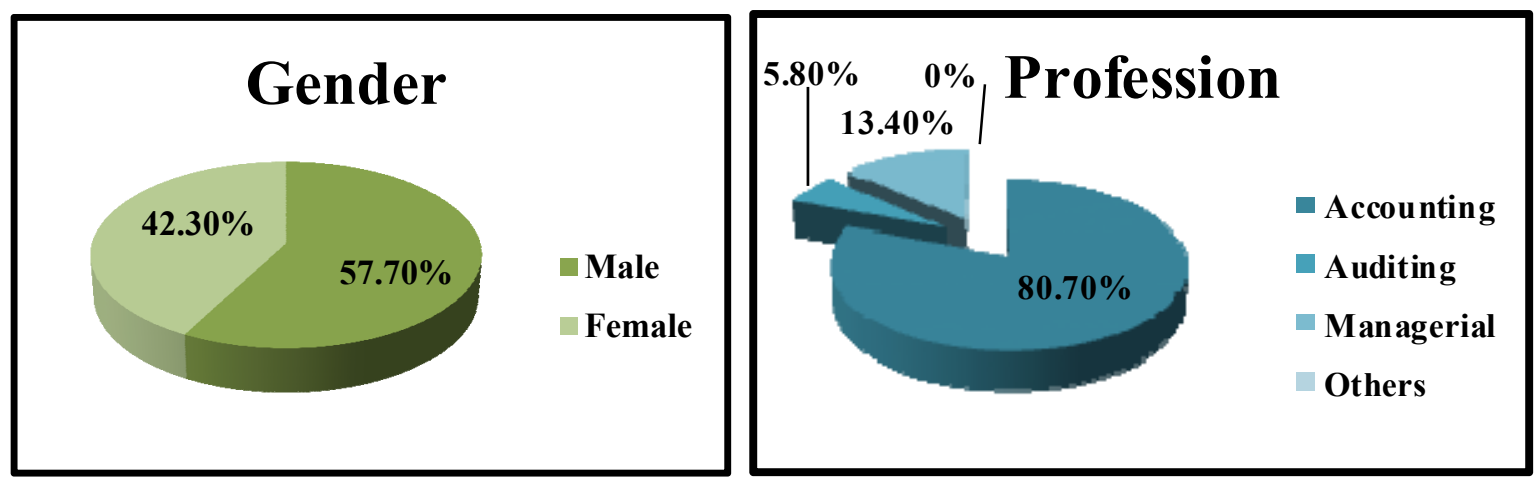

Pie chart 2. Respondents with respect to their profession and educational level

As presented in the above diagram, the professions of respondents were $80.7 \%$ have an accounting profession, 5.8\% have an auditing profession, and $13.4 \%$ have managerial profession and none of respondents have other professions. This implies that more of the accounting system activities were performed by accountants. Furthermore, the educational level of respondents shows that out of the total of respondents $86.5 \%$ of respondents have BA degree, about $13.4 \%$ have Master's Degree, and none of the respondents have PHD. This implies that educational level of workers in the organization is more of BA degree and accounting related activities are largely performed by them.

Table 1. Description of respondents with respect to their stay in the company

\begin{tabular}{llll}
\hline Background & No. of Year & Number of Respondents & Percentage (\%) \\
\hline \multirow{4}{*}{ Stay in the company } & 1) 0 -5 Year & 39 & $84.6 \%$ \\
& 2) 6-10 Year & 6 & $13.4 \%$ \\
& 3) $>10$ Year & 1 & $2 \%$ \\
\hline
\end{tabular}

Table 1 shows the length of time respondents stay in the company and as a result about $84.6 \%$ of the respondents are stay in between $0-5$ years, $13.4 \%$ are between $6-10$ years and $2 \%$ are stay in the organization for more than 10 years. This indicates that more of workers in the organization are stay between 0-5 years and work experience of those workers is not that much enough to become effective in performance.

Table 2. Respondents' response for the role of accounting system on the company's import-export trade

\begin{tabular}{|c|c|c|c|c|}
\hline No & Questions & $\begin{array}{l}\text { Responses } \\
\text { Choices }\end{array}$ & $\begin{array}{l}\text { Number of } \\
\text { Respondents }\end{array}$ & $\begin{array}{l}\text { Percent } \\
(\%)\end{array}$ \\
\hline \multirow{5}{*}{1} & \multirow{5}{*}{$\begin{array}{l}\text { In the long run existence of the company } \\
\text { the effectiveness of accounting system } \\
\text { has significant role for various sound } \\
\text { decisions. }\end{array}$} & SA & 29 & $63.4 \%$ \\
\hline & & A & 13 & $28.8 \%$ \\
\hline & & SD & 4 & $7.7 \%$ \\
\hline & & $\mathrm{D}$ & 0 & $0 \%$ \\
\hline & & SA & 42 & $92.3 \%$ \\
\hline
\end{tabular}


Accounting system has a vital role on the A efficiency and effectiveness of the SD company's import-export trade operations and activities.

Without the information gathered by the accounting system, management would lack the ability to plan and direct SD operations in achieving the company's goals.

As the strength of accounting system

4 pulls the company up, so its poor efficiency and performance will push the company journey down.

The company is receiving full benefit

5 from the accounting system employment on its import-export trade activities.

In the long run existence of the company the effectiveness of accounting system has not any significant role for various sound decisions.
$\mathrm{D}$

SA

A

D

SA

$A$

SD

D

SA

A

SD

$\mathrm{D}$

SA

A

SD

D
$0 \%$

$0 \%$

$7.7 \%$

34.6

$50 \%$

$7.7 \%$

$7.7 \%$

$50 \%$

$42.3 \%$

$7.7 \%$

$0 \%$

$34.6 \%$

$42.3 \%$

$7.7 \%$

$15.4 \%$

$0 \%$

$13.4 \%$

$28.8 \%$

$57.7 \%$

Table 3. Respondents' response for the effective application of accounting system principles and procedures

\begin{tabular}{|c|c|c|c|c|}
\hline No & Questions & $\begin{array}{l}\text { Responses } \\
\text { Choices }\end{array}$ & $\begin{array}{l}\text { Number of } \\
\text { Respondents }\end{array}$ & $\begin{array}{l}\text { Percent } \\
(\%)\end{array}$ \\
\hline \multirow{4}{*}{1} & \multirow{4}{*}{$\begin{array}{l}\text { Only business transactions that potentially } \\
\text { affect the company's operations must be } \\
\text { recorded as they occur. }\end{array}$} & SA & 16 & $34.6 \%$ \\
\hline & & $\mathrm{A}$ & 13 & $28.8 \%$ \\
\hline & & SD & 13 & $28.8 \%$ \\
\hline & & $\mathrm{D}$ & 4 & $7.7 \%$ \\
\hline \multirow{4}{*}{2} & \multirow{5}{*}{$\begin{array}{l}\text { Accounting system must provide information } \\
\text { on business transactions for use in directing } \\
\text { operations and for the preparation of timely } \\
\text { periodic financial statements on the basis of } \\
\text { GAAP or IFRS. }\end{array}$} & SA & 38 & $84.6 \%$ \\
\hline & & A & 4 & $7.7 \%$ \\
\hline & & SD & 4 & $7.7 \%$ \\
\hline & & $\mathrm{D}$ & 0 & $0 \%$ \\
\hline \multirow{4}{*}{3} & & SA & 32 & $71.1 \%$ \\
\hline & \multirow{3}{*}{$\begin{array}{l}\text { Keeping a separate record for each item on } \\
\text { the financial statement is needed. }\end{array}$} & $\mathrm{A}$ & 10 & $21.1 \%$ \\
\hline & & SD & 0 & $0 \%$ \\
\hline & & $\mathrm{D}$ & 4 & $7.7 \%$ \\
\hline \multirow[b]{2}{*}{4} & \multirow{2}{*}{$\begin{array}{l}\text { The individual records must summarize at } \\
\text { periodic intervals and the data thus obtained }\end{array}$} & SA & 10 & $21.1 \%$ \\
\hline & & $\mathrm{A}$ & 28 & $63.4 \%$ \\
\hline
\end{tabular}


are presented in the financial statements or other reports.

An accounting system must be tailored to

5 meet the specific needs of each business but it should be cost-effective.

Companies must adapt to the constantly

$\mathrm{SD}$

$\mathrm{D}$

SA

$\mathrm{A}$

SD

$\mathrm{D}$

SA

$A$

SD

$\mathrm{D}$

SA

$A$

SD

$\mathrm{D}$

Users of the information provided by the accounting system relays on various reports for relevant information presented in an understandable manner thus effective reporting is needed.

SA

$A$

SD

$\mathrm{D}$

SA

9 The accounting system must be tailored to the organizational structure of the company.

Using computerized system to automate the recording process is needed in order to reduce cost and process accounting data more effectively.

An accounting system must not be tailored to

11 meet the specific needs of each business but it should be cost-effective.
A

SD

$\mathrm{D}$

SA

$A$

SD

$\mathrm{D}$

SA

$\mathrm{A}$

SD

$\mathrm{D}$
$7.7 \%$

$7.7 \%$

$32.6 \%$

$57.7 \%$

$0 \%$

$7.7 \%$

$21.1 \%$

$71.1 \%$

$7.7 \%$

$0 \%$

$78.8 \%$

$13.4 \%$

$0 \%$

$7.7 \%$

$82.6 \%$

$7.7 \%$

$7.7 \%$

$0 \%$

$20.0 \%$

$7.7 \%$

$13.4 \%$

$57.7 \%$

$42.3 \%$

$50 \%$

$0 \%$

$7.7 \%$

$13.4 \%$

$0 \%$

$50 \%$

$36.5 \%$

Table 4. Respondents' response for the roles of accounting systems on the overall economy

\begin{tabular}{|c|c|c|c|c|}
\hline No & Questions & $\begin{array}{l}\text { Responses } \\
\text { Choices }\end{array}$ & $\begin{array}{l}\text { Number of } \\
\text { Respondents }\end{array}$ & $\begin{array}{l}\text { Percent } \\
(\%)\end{array}$ \\
\hline \multirow{4}{*}{1} & Accounting system can support sound & SA & 38 & $82.6 \%$ \\
\hline & decisions essential for the effective & A & 0 & $0 \%$ \\
\hline & distribution and use of the nation's scarce & SD & 4 & $7.7 \%$ \\
\hline & resource. & $\mathrm{D}$ & 4 & $7.7 \%$ \\
\hline \multirow{4}{*}{2} & Accounting has played an important role by & SA & 42 & $92.3 \%$ \\
\hline & providing the financial information needed & A & 0 & $0 \%$ \\
\hline & to achieve the desired goals of the & SD & 0 & $0 \%$ \\
\hline & government on economic and social matters. & $\mathrm{D}$ & 4 & $7.7 \%$ \\
\hline
\end{tabular}


As the company operates on import-export SA

3 trade, in measuring the countries balance of $\mathrm{A}$ payment the accounting system has $\mathrm{SD}$ $76.9 \%$ significant role.

D $\quad 4$

$7.7 \%$

$7.7 \%$

$7.7 \%$

Table 5. Respondents' response on relationships between accountant's competency and the effective of accounting system

\begin{tabular}{|c|c|c|c|c|}
\hline No & Questions & $\begin{array}{l}\text { Responses } \\
\text { Choices }\end{array}$ & $\begin{array}{l}\text { Number of } \\
\text { Respondents }\end{array}$ & $\begin{array}{l}\text { Percent } \\
(\%)\end{array}$ \\
\hline \multirow{5}{*}{1} & \multirow{5}{*}{$\begin{array}{l}\text { To perform accounting task accountants } \\
\text { should possess proper personal } \\
\text { knowledge, quality and skills. }\end{array}$} & SA & 23 & $50 \%$ \\
\hline & & $\mathrm{A}$ & 19 & $42.3 \%$ \\
\hline & & SD & 0 & $0 \%$ \\
\hline & & $\mathrm{D}$ & 4 & $7.7 \%$ \\
\hline & & SA & 34 & $76.9 \%$ \\
\hline \multirow[t]{4}{*}{2} & \multirow{4}{*}{$\begin{array}{l}\text { Accountants should be complying with } \\
\text { any professional ethics requirements. }\end{array}$} & A & 4 & $7.7 \%$ \\
\hline & & $\mathrm{SD}$ & 4 & $7.7 \%$ \\
\hline & & $\mathrm{D}$ & 4 & $7.7 \%$ \\
\hline & & SA & 13 & $28.8 \%$ \\
\hline \multirow{3}{*}{3} & \multirow{3}{*}{$\begin{array}{l}\text { I am following professional conducts } \\
\text { effectively for my tasks. }\end{array}$} & A & 27 & $57.7 \%$ \\
\hline & & SD & 0 & $0 \%$ \\
\hline & & $\mathrm{D}$ & 6 & $13.4 \%$ \\
\hline \multirow{4}{*}{4} & \multirow{4}{*}{$\begin{array}{l}\text { Accounting standards are effectively } \\
\text { followed while fulfilling professional } \\
\text { responsibilities in your company. }\end{array}$} & SA & 10 & $21.1 \%$ \\
\hline & & A & 32 & $71.1 \%$ \\
\hline & & SD & 0 & $0 \%$ \\
\hline & & $\mathrm{D}$ & 4 & $7.7 \%$ \\
\hline \multirow{4}{*}{5} & \multirow{4}{*}{$\begin{array}{l}\text { To perform accounting task accountants } \\
\text { should not possess proper personal } \\
\text { knowledge, quality and skills. }\end{array}$} & SA & 7 & $13.4 \%$ \\
\hline & & $\mathrm{A}$ & 0 & $0 \%$ \\
\hline & & SD & 10 & $21.1 \%$ \\
\hline & & $\mathrm{D}$ & 29 & $65.5 \%$ \\
\hline
\end{tabular}

\section{Non-Parametric Test: Testing Goodness-of-Fit and Independence, $\chi^{2}$}

This measure is used to measures the deference between observed $(\mathrm{O})$ and expected $(\mathrm{E})$ frequencies of nominal variables. One of the specific objectives of this research was identify the effect of accountant's competency on the effectiveness of accounting system. Thus, this survey was done to see the relationship between the effectiveness of accounting system and the accountant's competency.

In order that we tend to might apply the chi-square test either as a test of goodness of fit or as a test to evaluate the importance of association between attributes, it is necessary that the discovered as well as theoretical or expected frequencies should be sorted within the same means and therefore the theoretical distribution should be adjusted to provide similar total frequency as we discover just in case of observed distribution (Kothari, 2004). Thus, to calculate $\chi^{2}$ obs the researcher used the following formula: 


$$
\mathcal{X}^{2}{ }_{\mathrm{obs}}=\sum\left(\mathbf{O}_{\mathrm{ij}}-\mathbf{E}_{\mathrm{ij}}\right)^{2} / \mathbf{E}_{\mathrm{i}}
$$

Where; $\mathrm{O}_{\mathrm{ij}}=$ Observed (actual) frequencies in the $\mathrm{i}^{\text {th }}$ row and $\mathrm{j}^{\text {th }}$ column

Eij= Expected (theoretical) frequencies in the $i^{\text {th }}$ row $j^{\text {th }}$ column

Table 6. The effectiveness of accounting system and Accountant's competency

\begin{tabular}{lllll}
\hline Effectiveness & of & \multicolumn{2}{c}{ Accountant's Competency } & \multicolumn{2}{c}{ Total } \\
Accounting System & Profession & Educational Level & Work Experience & \\
\hline Effective & 9 & 6 & 3 & 18 \\
Not-Effective & 7 & 14 & 13 & 34 \\
Total & 16 & 20 & 16 & 52 \\
\hline
\end{tabular}

According to Kothari (2004), as a test of goodness of fit, $\chi^{2}$ test enables us to see how well the assumed theoretical distribution does fit to the observed data.

Table 7. Table for calculation of Chi-Square

\begin{tabular}{llllll}
\hline Group & $\begin{array}{l}\text { Observed } \\
\text { Frequency }\left(\mathbf{O}_{i j}\right)\end{array}$ & $\begin{array}{l}\text { Expected } \\
\text { Frequency }\end{array}\left(\mathbf{E}_{\mathbf{i j}}\right)$ & $\left(\mathbf{O}_{\mathrm{ij}}-\mathbf{E}_{\mathrm{ij}}\right)$ & $\left(\mathbf{O}_{\mathrm{ij}}-\mathbf{E}_{\mathbf{i j}}\right)^{\mathbf{2}}$ & $\left(\mathbf{O}_{\mathrm{ij}}-\mathbf{E}_{\mathrm{ij}}\right)^{\mathbf{2}} / \mathbf{E}_{\mathrm{ij}}$ \\
\hline $\mathbf{E P}$ & 9 & 5.54 & 3.46 & 11.9716 & 2.1609 \\
$\mathbf{E L}$ & 6 & 6.92 & -0.92 & 0.8464 & 0.1223 \\
$\mathbf{E W}$ & 3 & 5.54 & -2.54 & 6.4516 & 1.1645 \\
$\mathbf{N P}$ & 7 & 10.46 & -3.46 & 11.9716 & 1.1445 \\
$\mathbf{N L}$ & 14 & 13.08 & 0.92 & 0.8464 & 0.0647 \\
$\mathbf{N W}$ & 13 & 10.46 & 2.54 & 6.4516 & 0.6168 \\
Total & & & & & 5.2737 \\
\hline
\end{tabular}

$$
\chi_{\text {Obs }}^{2}=\sum\left(\mathrm{O}_{\mathrm{ij}}-\mathrm{E}_{\mathrm{ij}}\right)^{2} / \mathrm{E}_{\mathrm{ij}}=5.2737
$$

Therefore, degrees of freedom in this case $=(r-1)(c-1)=(2-1)(3-1)=2$. The tabular value of $\chi^{2}$ for degree of freedom (2) at 5\% significance level is 5.991. As a test of goodness of fit, the calculated value of $\chi^{2}(5.2737)$ is less than the table value at a $5 \%$ level of significance $\left(\chi^{2}=5.991\right)$. We can, thus, conclude that the fit is considered to be a good one which means that the divergence between the observed and expected frequencies is attributable to fluctuations of sampling

As stated by Kothari (2004), as a test of independence, $\chi^{2}$ test enables us to explain whether or not two attributes are associated. In such a state of affairs, we tend to proceed with the null hypothesis that the two attributes are autonomous. In this regard, the researcher wants to know the association between accounting system's effectiveness and accountant's competency. Thus, the researcher believes that there was a 5\% level of significance and tries to test null hypothesis and to give the possible conclusion. In order to get insight on this main 
objective, the researcher tests the following hypothesis:

$\mathrm{H}_{0}$ : There is no statistically significant relationships exist between the effectiveness of accounting system and accountant's competency

In order to test the above hypothesis, the researcher used the $\chi^{2}$ distribution and as it was analyzed in the previous pages, the degrees of freedom were 2 and the table value of $\chi^{2}$ for 2 degree of freedom at 5\% level of significance is 5.991. As a test of independence, the calculated value of $\chi^{2}(5.2737)$ is less than the table value at a $5 \%$ level of significance $\left(\chi^{2}=\right.$ 5.991) and hence the result of the experiment does support the hypothesis. We can, thus, conclude that there were no statistically significant relationships exist between the effectiveness of accounting system and accountant's competency. As the test implies the effectiveness of accounting system is merely determined by the accountant's competency i.e. their profession, educational level, and work experience they have at $95 \%$ confidence interval.

\section{Conclusions and Recommendations}

Based on the findings the researcher concludes on the following key points of the study. Thus, from the study it can be concluded that applying effective accounting system on the operations of the ones company has a significant role. Thus, in Anbessa Shoe Share Company import-export trade activities the effectiveness of accounting system has significant role for its long run existence and for various sound decisions made in the company. Furthermore, the researcher can conclude that the company is receiving full benefit from the accounting system employment on its import-export trade activities. In addition, the non-parametric test of chi-square test shows that the accountant's competency was statistically not significant enough at $5 \%$ significance level to have a relation with the effective accounting system of the company, therefore this conclusion needs future research and should think through for finding the association of them. The assumptions needed to be fulfilled for goodness-of-fit were tested and it revealed that the test statistics is fitted with the sample data.

Based on the findings of the study the following recommendations was made:

Though the company, ASSC, has an accounting system, it has to give more emphasis to the implementation problems of the system, where it can address using only its potentials and abilities with the accountant's competency. Therefore, the company is highly recommended to implement the proposed accounting system effectively, to make informed decisions by managements so as to bring total company performance improvement and being competitive.

The export lead strategy of the government is better meaning for developing competitiveness of Anbessa Shoe Share Company internationally due to the technology transfer (knowledge, new designs, techniques and methods whereas taking their design) in between native corporations and foreign customers. So, it is highly recommended that Anbessa Shoe Share Company has to work more on it because export strategy can drive the native one.

Accounting system is effective when it is cost-effective balance, flexible to meet future needs, adequate internal control, effective reporting, and it should be tailored to the adopted organizational structure. Thus, it is highly recommended to the company that to fulfill those criteria on its accounting system in order to make it more effective. 
Since, the test implies there were no statistically significant relationships exist between the effectiveness of accounting system and accountant's competency, the company is highly recommended that when performing an accounting tasks, accountants should be competent enough to be more effective and to achieve good performance in operations and to make the competency having a major impact in the company's accounting system.

\section{References}

Abdulkadir, N. (2010). Senior Essay Project: Accounting and Reporting Problems of Import-Export Trade, Addis Ababa University, Ethiopia.

Berhe, A. (2009). Master Thesis of Arts in Regional and Local Development Studies. Assessment of Hides and Skins Marketing, Addis Ababa University, Ethiopia.

Derresse, D. (2011). Third Ethio-Chamber International Trade Fair, Capital News Paper, ASSC, Addis Ababa, Ethiopia.

Eliffson, T. (2006). Auditing Principles: Auditing and Assurance Service International, $8^{\text {th }}$ edn, Mc Grow Hill Press, USA.

Haberler, G. (1964). Comparative Advantage, Agricultural Production and International Trade. The International Journal of Agrarian Affairs, May.

Kothari, C. R. (2004). Research Methodology Methods and Techniques. New Age International Publishers Ltd., New Delhi, India.

Larson, K. D., Zin, M., \& Nelson, M. (1990). Fundamentals of Accounting (6th ed.). Von Hoffmann presses Inc, USA.

Meade, J. (1951). The Balance of Payments, Oxford University Press, London.

Ricardo. (1987). Principle of Political Economics and Taxation (3rd ed.). Irwin, Homewood.

Salvatore, D. (2011). International Economics: Trade and Finance (10th ed.). John Wilex and Sons Inc., Singapore.

Smith, A. (1937). The Wealth of Nations. The Modern Library, New York.

UNIDO, M. (2004). A Strategic Action Plan for the Development of the Ethiopian Leather and Leather Products Industry: Integrated Plan for Ethiopia, Vol. 1, Addis Ababa, Ethiopia, $15-19^{\text {th }}$ July.

Warren, F. (2006). Principles of Accounting: Accounting Principle and Practice, Orange Printing Press, USA.

Weygandt, J. (1993). Accounting Principles (3rd ed.). Wiley Printing Press, New York.

Yakob, A. (2002). An Audit of Livestock Marketing Status in Kenya, Ethiopia and Sudan. Issues in the Marketing of Livestock in Kenya, Ethiopia and Sudan, CAPE, OAU.

Zewdu, K. (1995). Hides and skins in Ethiopia, The PhD Dissertation Presented to Verlag Koster University, Berlin.

\section{Copyright Disclaimer}

Copyright for this article is retained by the author(s), with first publication rights granted to the journal. This is an open-access article distributed under the terms and conditions of the Creative Commons Attribution license (http://creativecommons.org/licenses/by/3.0/). 